\title{
Principle of Circular and Cumulative Causation: Fusing Myrdalian and Kaldorian Growth and Development Dynamics
}

\section{Phillip Anthony O'Hara}

\begin{abstract}
This paper seeks to promote the development of the principle of circular and cumulative causation (CCC) through integrating social and economic dimensions as applied to historical problems. It starts by examining the similarities and differences between Myrdalian and Kaldorian circular and cumulative causation. It shows that the similarities help link the approaches, while the differences enable complementary specializations. There are core elements in both traditions plus specializations that are complementary. A degree of convergence exists between these traditions of institutional and post Keynesian schools, enhancing the analytical spread of vision of contemporary political economy.
\end{abstract}

Keywords: circular and cumulative causation, Gunnar Myrdal, Nicholas Kaldor, institutional and post Keynesian political economy

JEL Classification Codes: B52, E12, 042, P16, Z1

Circular and cumulative causation (CCC) has been a critical principle of political economy for over a hundred years. While the roots of the concept go back further (see Humphrey 1990; O'Hara 2000), Thorstein Veblen (1857-1929) utilized the concept in his examination of the evolution of institutions. Gunnar Myrdal (1898-1987) scrutinized the conditions of African Americans and Asian underdevelopment through the lens of CCC; influenced as he was by Knut Wicksell (1851-1926) (Myrdal 1939). Nicholas Kaldor (1908-1986) applied CCC to the role of manufacturing in capitalist growth; influenced by Adam Smith (1723-1790) and Allyn Young (18761929). Numerous other scholars have utilized the notion of CCC, often in different

The author is a Professor of Global Political Economy $\mathcal{B}$ Governance and Director of the Global Political Economy Research Unit (GPERU) in the Department of Economics, Curtin University, Perth, Australia. Email: philohara@yahoo.com. This paperwas prepared for presentation at the annual meetings of the Association for Evolutionary Economics in New Orleans, January 2008. The author wishes to thank Rick Adkisson, Sebastian Berger, Wolfram Elsner, Mathew Forstater and Vicki Taggart for advice and assistance with this paper. The usual caveat applies. 
ways. There are linkages between Veblen, Myrdal and Kaldor. For instance, Veblen influenced Allyn Young who in turn taught Kaldor; Myrdal got the concept from Knut Wicksell and worked with Kaldor at the United Nations (Economic Commission for Europe); and Kaldor $(1970,142)$ got the term from Myrdal.

The first main section, studies the similarities and differences between the Myrdalian and Kaldorian CCC frameworks. The second section develops a general system model of integration between the two traditions. There is a large measure of continuity between the two CCC approaches; they complement each other. Myrdalian CCC concentrates on the social provisioning aspect of development, while Kaldorian CCC centers on demand-supply relationships linked to the manufacturing sector. Linking both CCC approaches in an integrative model enhances our understanding of development and growth dynamics, and contributes to the development of institutional-evolutionary political economy.

\section{Comparison of Myrdal and Kaldor on CCC}

Myrdalian and Kaldorian CCC traditions have significant commonalities as well as important differences. They have three main things in common. The first is the principle of circular causation, where the variables are interrelated, and the general manner of interaction between variables is complex and manifold. Circular causation is a multi-causal approach where the core variables and their linkages are delineated. CCC eschews single factor theories. Both Myrdalian and Kaldorian CCC examine circular relationships, where the interdependencies between factors are relatively strong, and where variables interlink in the determination of major processes.

The second similarity is cumulative causation, where the variables tend to operate as positive feedback processes, magnifying and multiplying the combined impact of the interactions through historical time. The coefficients of interaction between variables will play some role here, as will the extent of any negative feedback (drawback) effects working in the opposite direction. These cumulative interactions are crucial to Myrdalian and Kaldorian empirical studies of money, growth, demand, development and ethnicity. Both forms of CCC examine cumulative dynamics, where the feedback within and between variables often tend to have a multiplier or amplified impact on the overall outcomes.

The third similarity relates to traverse, path dependence, and hysteresis that move the system through time in a typically non-equilibrium fashion. Both approaches to CCC recognize the importance of history and time, as well as space and geography, since changes to the social and political economy condition the path of evolution and transformation; and there are regional differences to growth and development as well. The acquisition of knowledge, technical skills and economies of scale/scope affect the path of growth and development in complex and multifarious ways. Both theories explain real world processes that impact nations and regions, and which help explain differences in the outcomes between regions and areas.

The fourth similarity is that cumulative processes often have endogenous contradictions embedded in their dynamics. This aspect has been under-emphasized 
in the literature, yet it is very important since it means that cumulative changes may sow the seeds of their own demise. When David Gordon (1991), for instance, criticized Kaldor's theory for having too much cumulation and not enough contradiction, he was cognizant of the problem but underplayed the degree that Kaldor himself recognized the problem (e.g., see Kaldor 1966). Setterfield (2001) has set the record straight for Kaldor, since, for instance, regimes of accumulation often have norms and mores that become locked-in, even when industrial change is required (see also Argyrous 2001 and Toner 2001). For Myrdal, on the other hand, the contradictions are more obvious, since cumulation occurs more specifically in tandem with uneven development; and counteracting forces can often be strong (though themselves cumulative, perhaps in a different direction).

These are strong similarities; core ones. Indeed, they are the foundation for linking the traditions. However, the differences are also important, since they allow the traditions to examine marginally different (but complementary) problems. There are three main differences between the models, differences of emphasis rather than quality. The first is that Myrdalian CCC concentrates on the social economy and development through interdisciplinary analysis; whereas Kaldorian CCC centers on more technical demand-supply issues linked to economies of scale and growth. Although Myrdal started out applying CCC to money and macroeconomics (Myrdal [1939] 1965), his most famous two-volume application was to the under-privileged situation of African Americans in the United States (Myrdal 1944), along with his three-volume work on Asian underdevelopment (Myrdal 1968). Myrdal influenced others to apply the theory to issues such as the provision of public and social services in rural and remote areas (Fagence 1980), the socio-political crisis in Poland in the 1980s (Tarkowski 1988), and uneven development at the regional level (Higgins and Savoie 1995). Myrdal's holistic vision is consistent with an interdisciplinary method for the social sciences, broadening the field of inquiry to social, political and economic relationships (see Hawley 1979).

Kaldor's CCC was a narrower economic approach to linking demand with supply through interdependencies with investment spending, productivity and world income. He placed more emphasis than Myrdal on the growth impact of CCC processes in domestic, regional and world economies. Kaldor (1972; 1975; 1980) recognized the importance of history and time, especially investment demand being embodied in scaled economies and regimes of accumulation. He stimulated other economists to apply his analysis to issues of industrial maturation and demise in the United Kingdom (Eatwell 1982), the balance of payments constraint (McCombie and Thirlwall 1994), and regimes of accumulation (Pini 1995). Kaldor's vision is narrower than Myrdal's yet still recognizing the importance of multi-causal processes and longterm change.

Secondly, the Myrdalian system is more values-oriented, concerned with the role of ideology, assumptions, social norms and mores; whereas the Kaldorian system is seemingly more objectively founded on evidence and empirical evidence (Berger 2008). Thus, Myrdal emphasizes the normative elements of inquiry, recognizing the 
role of human relationships and psychological preconceptions in the grounding of economic processes. Kaldor, on the other hand, to some degree takes for granted the cultural fabric and psychological foundations of human behavior; concentrating on the more obvious productive, sectoral and organizational linkages within the economy.

Thirdly, the Myrdalian system concentrates more on the uneven process of development, especially vis-à-vis minority groups and underdeveloped nations (e.g., African Americans; Asian social economies). The Kaldorian model, on the other hand, is a forward-looking view of CCC as the driving force of capitalism, for those regions that are pushing ahead of the pack (while recognizing regional uneven growth). Therefore, Myrdal centers on the groups and nations or areas that are less wealthy, whereas Kaldor's core concern is the differential in terms of the forward (and contradictory) motion of the dominant areas.

It is also true that the above differences are overplayed somewhat and that Myrdal and Kaldor had much in common even at these levels; as Toner (1999, 110. 112,115-116,159) recognizes. For instance, Myrdal emphasized economies of scale, but with an institutional flavor, while Kaldor at times looked to an institutional and political explanation. Institutional aspects of Kaldor's theory are very important, even if seldom recognized (Setterfield 1997). Hodgson (1989) argued that the highly mechanical nature of manufacturing may stimulate economies of codified knowledge; and that manufacturing can more easily aggregate economies in compact spatial centers, resulting in greater diffusion and dissemination of knowledge. It is also possible that institutional and historical factors associated with flexible norms and routines, as well as changes to the socioeconomic environment, may stimulate a productivity edge for some nations and areas. Indeed, Kaldor's (1966, 110-112) emphasis on the manufacturing sector often linked to transport, utilities and communications externalities.

The similarities between Myrdal and Kaldor help us recognize their common method and practices, while the differences (which concern degrees and core concerns) enabled them to concentrate on somewhat different levels of analysis. Myrdalian and Kaldorian differences complement each other when it comes to CCC. This is so because Myrdal concentrates on the social economics of CCC while Kaldor centers on the supply-demand dynamics of CCC. A degree of specialization was thus possible, where Myrdal and associates could concentrate on socioeconomic development and inequality, while Kaldor and colleagues centered on laws of manufacturing and supply-demand interactions. Both types are well developed, and from this knowledge base, we are able to detail their manner of interaction (see O'Hara 2007a).

Due to linkages and innovations introduced into Myrdalian and Kaldorian CCC, it is useful to merge the two traditions. This merger will widen the sphere of knowledge and application within contemporary political economy. The next section illustrates this fusion into a general Myrdalian - Kaldorian system of CCC. 


\section{General System Integration of Myrdalian - Kaldorian CCC}

Here we develop a dual model of interaction between the social economy and demand-supply conditions for growth and development. In developing this model, some perceived problems with Myrdalian and Kaldorian CCC are implicitly eschewed (e.g., those discussed by Oliver Cox 1948). This model develops with the following integral conditions and assumptions for linking Myrdalian and Kaldorian CCC:

1. Values and Culture: The starting point of CCC is the analysis of the role of culture in the socioeconomic process. We need to recognize the significance of ideology, paradigms, human relationships and various norms and mores. We also recognize that the real world does exist, and that the critical task is to situate the causal linkages between these elements of the social economy.

2. Stylized Facts: It follows logically that if we first understand the causal linkages between economic agents' valuation of the facts and their interactive relationships, then we can go forward and situate the more technical elements of the stylized facts. Economic theory should be realistic in trying to base policies and practices on empirical regularities and stylized facts. Institutions, industries, and trends are the foundation for a pragmatic political economy of capitalism and its alternatives. Results considered now may change in the future as new processes and transformations come into play.

3. Multi-Factor Approach: Single factor theories should be eschewed in favor of broader approaches that recognize the importance of the social, political and economic elements set in an environment of ecological sustainability. A breadth of vision is required to comprehend most problems. These factors are cultural, socioeconomic and technical. The general and technical factors are complementary in a wider CCC framework.

4. Circular Causation: Circular causation is very useful whether it be one of complete independence between variables or a circuitous-directional process of interaction. It is critical for the variables to interact through time in complex ways and for relationships to evolve through historical time. Circular causation also recognizes the need to transcend a narrow study of socioeconomic institutions through linking specific institutional spheres (such as the financial system) to other spheres and relationships (such as households and governments). The broad socioeconomic and the more technical economic factors interact in the CCC process.

5. Cumulative Causation: Over long historical time, cumulative forces impact on the economy, as the linkages between major factors generate amplified and multiplied results from the initial changes. A change somewhere along the line is likely to have effects much greater than the initial ones. These effects are ongoing, usually not equilibrium-generating, and systemic in the impact. The interaction between the general and technical CCC factors stimulates more cumulative motion than when the socioeconomic and technical are separate. Over time, transformations occur in the relationship between institutions and individuals, linking as they do to habits.

6. Reinforcing Tendencies. The secondary and tertiary changes will generally support the first, since various reinforcing effects operate in the economy. These reinforcing trends are of three main types. The first are the "trends to inequality" 
between regions and groups, as some move ahead while others are retarded. The second are "internal and external economies," with externalities tending to be rampant, which reinforces inequality between areas and groups. The third are "spread effects," as forward-looking impacts expand regions and groups, magnifying the initial changes.

7. Path Dependence and Lock-In. One always needs to assess the relative importance of the reinforcing and counteracting forces. Irreversibility and path dependence lead to the inability of the system to move back to the original equilibrium position. The previous equilibrium is unlikely in the future, while a new equilibrium may not be forthcoming. The original changes - initial conditions - may set in motion forces conducive to the successful development and extension of a regime of accumulation (for a nation or region). This regime may also lead to certain institutional and social relationships stimulating evolution throughout the social economy.

8. Counteracting Forces or Contradictions. The cumulative upward expansion or decumulation may be moderated by a whole series of forces, such as exogenous shocks, policy interference, negative externalities, industrial maturation, and floors/ ceilings to the cycle; plus changes in wages, population and enterprise profit. For instance, endogenous motion may eventually lead to the maturation of the regime of accumulation as the product cycle moderates. This may lead to lower growth as the habits and institutions are not conducive to structural changes in the regime (O'Hara 2007b). Other endogenous contradictions may also emerge, such as labor shortages as the number of rural workers decline; plus higher wages, material costs and interest rates (Sherman and Kolk 1996).

9. Waves of Change. Sometimes these changes are so great that they create major historical processes or waves of change. During these times, parameters change, relationships between factors modify, and roles people play evolve. These waves of change generate potentialities that may result in new phases of development and growth over long historical time. Including both the general and technical factors in dynamic motion potentially increase the lags, and thereby stimulate periodicity and amplitude of the waves of change (see O'Hara 2007c).

10. Social Foundations of Development. Since "the movement of the whole social system upward is [what is] meant by development" (Myrdal 1968, 1868), the conditions necessary for development are broad and inclusive. Figure 1 illustrates how the socioeconomic institutions of capitalism may lead to a movement upwards of the whole social system, while simultaneously generating inequality as other nations and groups suffer a relative downgrade.

The social element of CCC starts by recognizing that CCC dynamics apply to ethnic, class and gender differences, as well as to national and regional dimensions of development. These cultural aspects of development and long-term transformation are critical to CCC. Whether we are looking at the problems of African Americans in an environment of a contradictory American creed of democracy, or problems of Asian development, this view of CC takes a long-term perspective of cultural transformation. Figure 1, outlines some of the major processes involved. 
Figure 1. Cultural and Socioeconomic CCC Dynamics

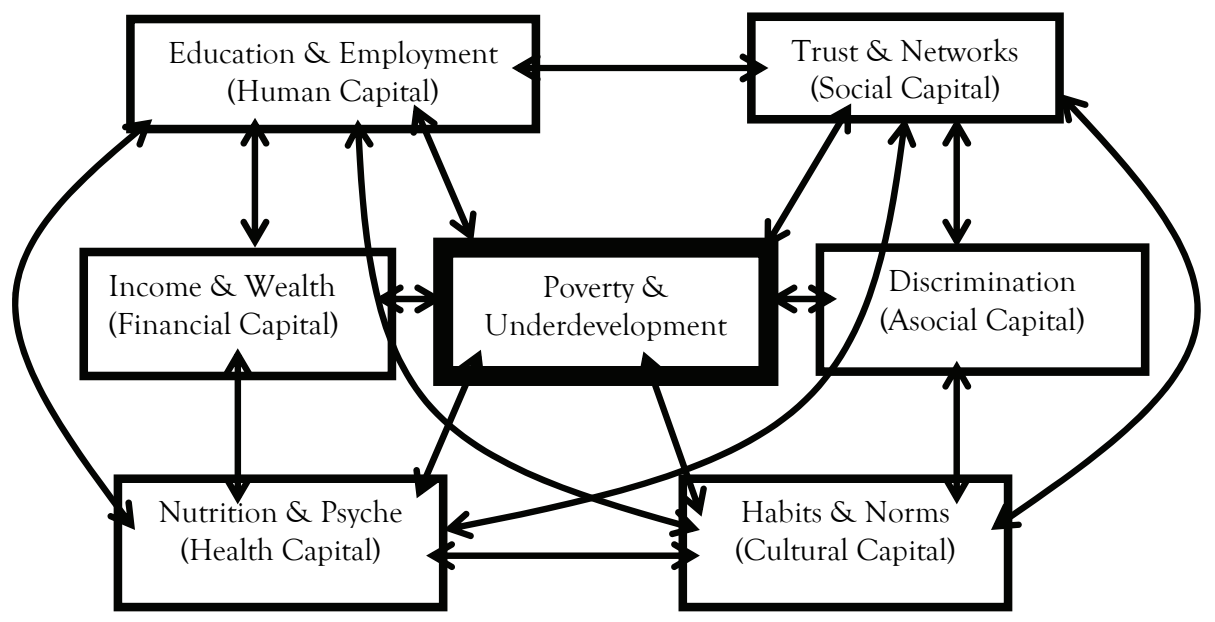

This figure shows that poverty and underdevelopment - and its opposite, wealth and development - are historically associated with six main factors in complex ways. These factors include education and employment (human capital channels), trust and networks (social capital channels), prejudice and discrimination (Asocial capital channels), habits, norms and mores (cultural capital channels), nutrition and psyche (health capital channels), as well as income and wealth (financial capital channels). These six forms of capital - human, social, Asocial, cultural, health, and financial help to determine and in turn are influenced by the processes associated with poverty and underdevelopment (and its opposite, material progress and development) (O'Hara 2001). The critical thing here is interdependency: factors interact in multiple and complex ways, impacting on poverty and underdevelopment. One needs to scrutinize their realistic interaction through time via qualitative and quantitative explanations. As Myrdal recognized, linkages are circular (in complex ways), and their impact through long historical time tends to be cumulative (Myrdal [1944] 1958).

Individuals, classes, genders, ethnic groups, nations, regions and even organizations that are able to accumulate various forms of capital tend to develop and accumulate in an ongoing fashion. The groups that lag behind fall away relatively and perhaps absolutely. The circular and cumulative interactions of factors affect poverty and underdevelopment, as well as material progress and development. The cultural, institutional, political and even psychological factors play a role in economic processes as cybernetic and feedback interactions come into play. Both qualitative and quantitative elements are important in this full array of interdependencies.

On the one hand, areas or groups can surge ahead as they advance technologically, knowledge and skills accumulate, networks and organizations are formed, progressive habits and norms come into play, while nutritional and 
psychological factors improve ("spread effects"). Other areas lag behind because they lack resources, path dependent expansions, and institutional innovations; and these disadvantages encourage discrimination and prejudice, such as in the case of the African Americans verses White Anglo Saxon U.S. citizens; or Asian nations versus the impressions of citizens in advanced nations (in the 1960s). One group or area may have cumulative upswing while the other experiences a vicious circle as one plane of living expands while the other is inhibited. The cumulative process will tend in this way to generate greater inequalities (Myrdal 1957, 12).

There could emerge, of course, counteracting forces to these specific cumulative ones, such as "exogenous factors," policy changes, and so on, which may have opposing impacts. As Myrdal (1957, 13) noted, however, these "backwash" factors are unlikely to propagate equilibrium tendencies; instead stimulating cumulative forces in a different direction. While to some degree, for instance, government policies "cannot [radically] change folk ways"; as Myrdal noted, they can condition them, moderate them, encouraging alternative folkways or changes in existing ones. Either way, the path dependent process continues, perhaps in multiple directions and dimensions, toward more complex forms. Some degree of relative socioeconomic "tranquility" is also possible through the dynamic interplay of circular and cumulative forces; but this is not a static or even dynamic equilibrium. Rather, it is the cumulative interaction of forces propelling low levels of relative instability and conflict, at least for a time.

In Figure 2, we simplify the cultural and socioeconomic aspects of CCC by the use of a 4-segment quadrant. This 4-segment quadrant illustrates a simple upward movement for a nation (and dominant group), while also illustrating that a minority group is unable to benefit to the same degree as the dominant group due to low (relative?) levels of resources, plus discrimination and prejudice. Segment A shows that human capital and income are positively related, as are social networks and income in Segment B. Segment C shows that discrimination declines when networks rise, while Segment D illustrates that discrimination declines with higher levels of human capital.

Linking the original curves generates equilibrium results (through a pure "fluke"). When change occurs, such as an upward movement in the income/networks nexus, from $\mathrm{Y} / \mathrm{N}_{\mathrm{o}}$ to $\mathrm{Y} / \mathrm{N}_{1}$, due to the relationship between variables, circular and cumulative causation sets in. As networks stimulate more economies, income expands, which enables people to generate human capital, which reduces discrimination for those with capital and greater networks. Positive results occur as CCC motion generates a wave of upswing through the system. In this example, there are no endogenous contradictions except that those who were not included in the more effective networks and knowledge have fewer relative resources and perhaps more discrimination against them. This links in the current environment, for instance, to lower conditions of existence in sub-Saharan Africa and much of Latin America. 
Figure 2. Cultural and Socioeconomic 4-Segment CCC Quadrant

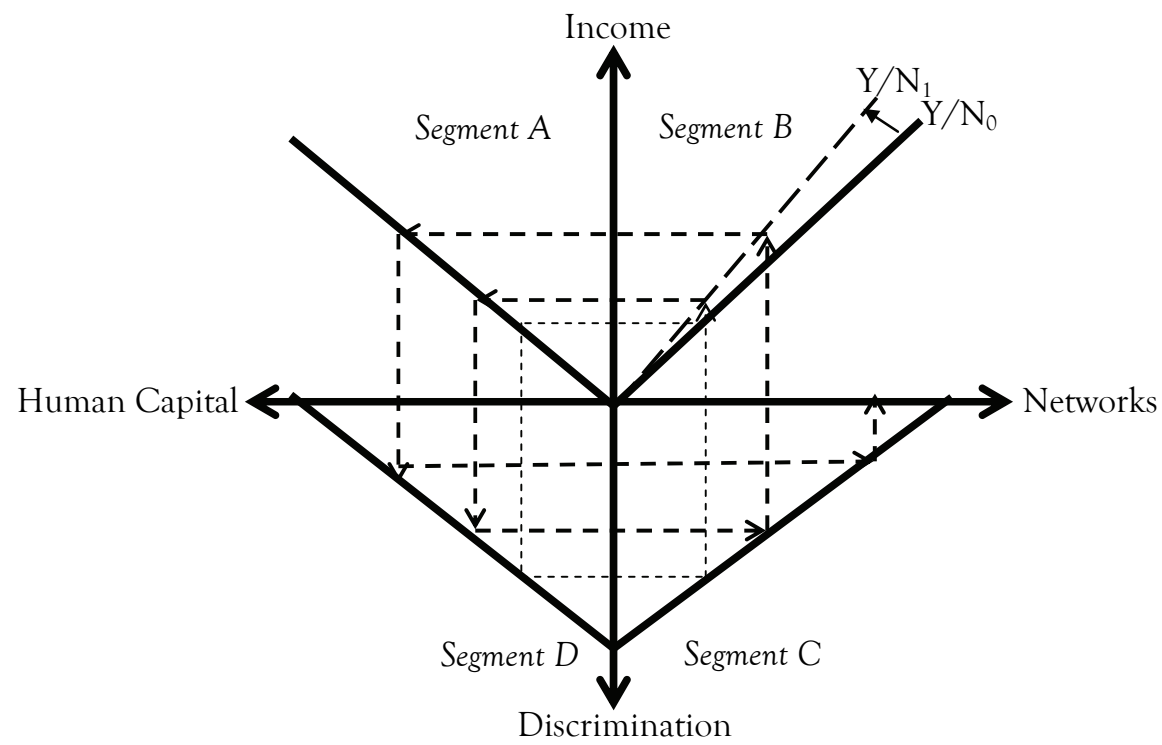

11. Technical Foundations of Long-Term Growth. Demand-Supply CCC is somewhat more technical, but still in continuity with the cultural and socioeconomic aspects of CCC (Skott 1999). The technical details concern the nature of the capitalist system, scaled economies, demand and productivity. In modern parlance, it is important to link demand-supply dynamics with technological change and economies of scale/ scope, as the model becomes more realistic, as shown in Figure 3.

Figure 3. Kaldorian CCC Dynamics

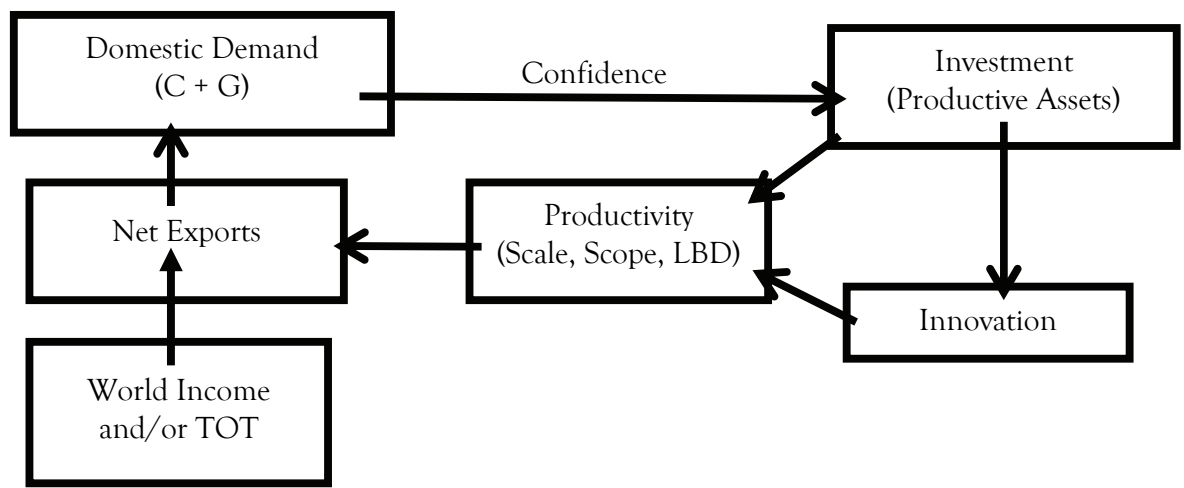


This shows how demand is the core of the problem, and that it is interdependent with supply. A strong level of domestic demand by itself and in relation to other factors, can help provide an environment where confidence is relatively high (uncertainty low), thereby stimulating investment at a relatively high rate. Investment can generate productivity increases through economies of scale, scope and learning by doing (LBD) (Verdoorn's Law), with spatial agglomeration, infrastructure and communications externalities playing critical roles; as well as through innovation. Demand and supply are thus interdependent, rather than the usual independent (supply) and dependent (demand) analysis of orthodoxy. A strong level of domestic income spurs productivity, which stimulates net exports, especially if the system of international finance is stabilizing and productive rather than overly speculative.

Critical here is the level of world income, which if high when uncertainty is relatively low can stimulate global trade. If the global environment has low levels of uncertainty, governments are cognizant of the need for productive public investment, and global finance stimulates relatively balanced systems of payment, then global exports can expand. This in turn stimulates domestic demand and investment, and through successive movements of the circuit also innovation and productivity, and so on ad infinitum. Nations with the leading sectors can especially undergo high levels of growth and prosperity. The circular and cumulative workings of capitalism can stimulate waves of upswing, as well as uneven development between the leading and underdeveloped nations. These circular and cumulative dynamics do not simply produce growth in the center and uneven development in the world. The workings of endogenous contradictions have led core nations to undergo maturation through lock-in of specific regimes of accumulation, that are incapable of evolving into higher forms; and through declining underemployment as rural labor dries up; as industrial centers mature.

Once the cultural and social foundations are developed the more technical economic aspects can expand; and visa versa. If the nation or region in question is able to evolve from agriculture and mining through to highly productive manufacturing, transport, communications and utility sectors, economies can be generated through scale, scope and innovation. With relatively low levels of uncertainty, higher investment can stimulate the creation of a new regime of accumulation. This new regime creates winners and losers, but if world income is at high levels, the losers may be less numerous than the winners due to an expansion of productive world investment. Over time, though, the regime may dissipate as anomalies evolve.

Figure 4 isolates core elements of the process through a simple 4-segment quadrant. With no change in the parameters, equilibrium may prevail along existing linear curves, such as $\mathrm{P} / \mathrm{Y}_{\mathrm{o}}$, (by a "fluke"). When a new accumulation regime emerges, through a new investment/productivity dynamic, a new productivity/income curve arises in Segment B (from $\mathrm{P} / \mathrm{Y}_{\mathrm{o}}$ to nonlinear curve $\mathrm{P} / \mathrm{Y}_{1}$ ). The consequent greater investment initially generate economies of scale and innovation with higher productivity and greater world income. Higher world income increases exports, which expands income, as multiple rounds of circular and cumulative dynamics ensure. 
Figure 4. Demand-Supply 4-Segmemt CCC Quadrant with Endogenous Contradictions

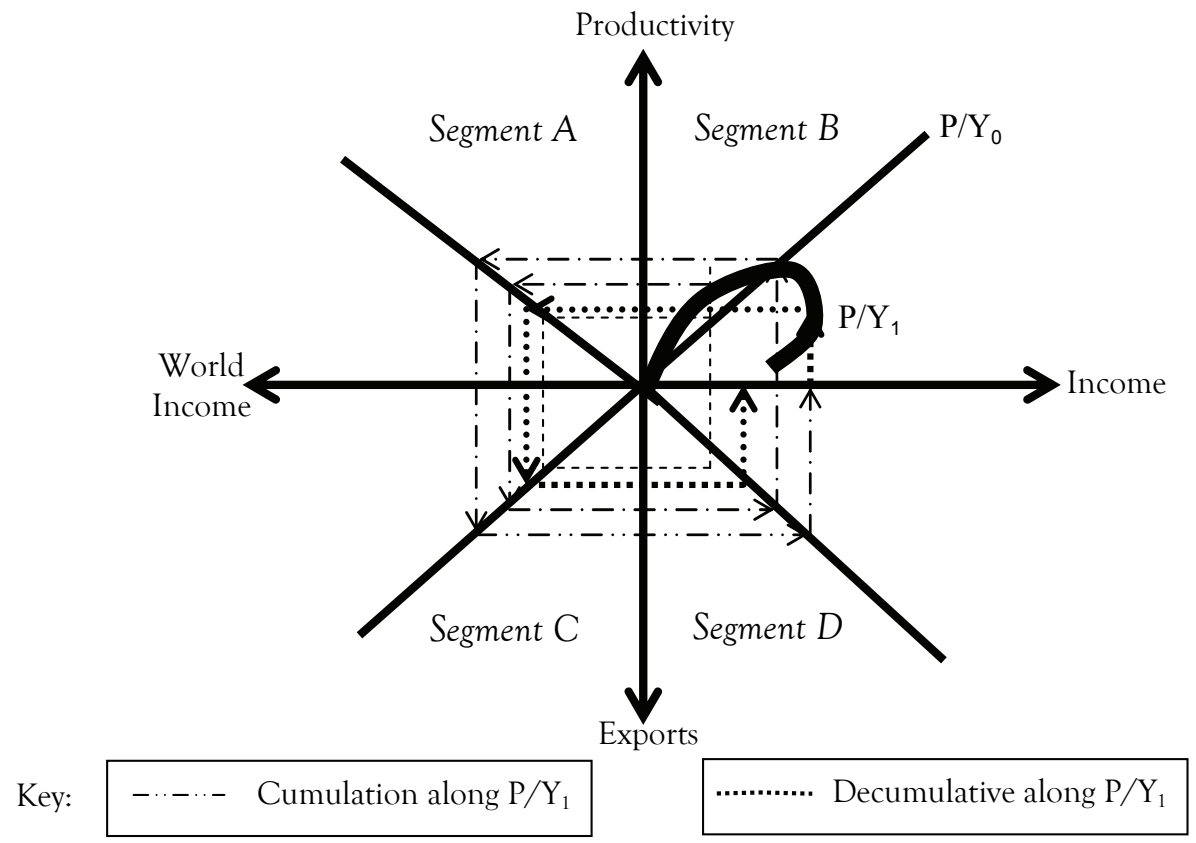

However, it is important to illustrate some contradictions in the model. The new regime of accumulation introduced with the nonlinear curve $\mathrm{P} / \mathrm{Y}_{1}$ has an area that generates cumulation, but also an area of decumulation as the circle traverses in Segment B. There could be multiple causes of this contradictory motion. A lock-in of technology can occur as the regime of accumulation fails to adjust to a more viable one as maturation occurs (due to established industrial habits and norms). Another is a decline in levels of underemployment as rural labor supply is exhausted through the movement to industry. These are the sort of factors discussed by Kaldor (1966) and Eatwell (1982) in their account of Britain's economic malaise. (For contemporary examples of uneven growth and development CCC dynamics see O'Hara 2007c.)

These simple figures and quadrants show how Myrdalian CCC can be formally linked with Kaldorian CCC to enhance growth and development theory. Myrdalian social development is both a pre-requisite and co-requisite for Kaldorian CCC; and visa versa. The explanatory power of CCC increases when the two are linked. The two CCC frameworks complement each other. 


\section{Conclusion}

This paper examined key aspects of circular and cumulative dynamics through works in the Myrdalian and Kaldorian traditions. There are many similarities, while the differences are complementary. Myrdal concentrated on the social foundations of development, while Kaldor scrutinized the technical foundations of long-term growth. Both are necessary for a fully-fledged scrutiny of the development and growth process. Linking cultural-socioeconomic aspects of CCC with technical demand-supply CCC advances the explanatory power of political economy.

\section{References}

Argyrous, George. "Setterfield on Cumulative Causation and Interrelatedness: A Comment." Cambridge Journal of Economics 25 (2001): 103-108.

Berger, Sebastian and Wolfram Elsner. "European Contributions to Evolutionary Institutional Economics: The Cases of Cumulative Circular Causation (CCC) and 'Open Systems Approach' (OSA). Some Methodological and Policy Implications.” Journal of Economic Issues 41, 2 (2007): 529-537.

Berger, Sebastian. "Circular Cumulative Causation a la Myrdal and Kapp: Political Institutionalism for Minimizing Social Costs." Journal of Economic Issues 42, 2 (2008): forthcoming.

Cox, Oliver C. Caste, Class and Race: A Study in Social Dynamics. New York: Monthly Review Press, 1948.

Eatwell, John. "The Principle of Cumulative Causation." Chapter 3 of John Eatwell, Whatever Happened to Britain? The Economics of Decline. London: Duckworth, 1982.

Fagence, Michael. "The Provision of Social and Other Services in Areas Experiencing Depopulation." Social Policy and Administration 14, 2 (1980): 91-114.

Gordon, David M. “Kaldor's Macro System: Too Much Cumulation, Too Few Contradictions.” In Nicholas Kaldor and Mainstream Economics, edited by Edward J. Nell and Wally Semmler, pp. 355-383). New York: St. Martin's Press, 1991.

Hawley, Amos H. "Cumulative Change in Theory and History.” In Societal Growth: Processes and Implications, edited by Amos H. Hawley, pp. 19-29. New York \& London: Macmillan, 1979.

Higgins, Benjamin and Donald J. Savoie. Regional Development Theories and their Application. New Brunswick, US: Transaction Publishers. 1995.

Hodgson, Geoffrey M. "Institutional Rigidities and Economic Growth.” In Kaldor's Political Economy, edited by Tony Lawson, J. Gabriel Palma and John Sender, pp. 79-101. London: Academic Press, 1989.

Humphrey, Thomas M. "Cumulative Process Models from Thornton to Wicksell." In Perspectives on the History of Economic Thought, Volume IV: Keynes, Macroeconomics and Method, edited by D.E. Moggridge, pp. 40-52. Aldershot, UK \& Brookfield, U.S.: Edward Elgar Publishing, 1990.

Kaldor, Nicholas. Causes of the Slow Rate of Economic Growth in the United Kingdom. Cambridge, UK: Cambridge University Press, 1966. Reprinted in Nicholas Kaldor, Further Essays on Economic Theory. New York: Holmes and Meier Publishers, 1978, pp. 100-139.

—. "The Case for Regional Policies." Scottish Journal of Political Economy 27, 3 (1970). Reprinted in Nicholas Kaldor, Further Essays on Economic Theory. New York: Holmes \& Meier Publishers, 1978, pp. 139-154.

—. "The Irrelevance of Equilibrium Economics." Economic Journal 82, 328 (1972): 1237-1255. Reprinted in The Essential Kaldor, edited by Ferdinando Targetti and Anthony P. Thirlwall, pp. 373-398. New York: Holmes and Meier, 1989.

—. "What is Wrong with Economic Theory." Quarterly Journal of Economics 89, 3 (1975): 347-357.

- Economics Without Equilibrium. Armonk, NY: M.E. Sharpe, 1980. Preface by James Tobin.

McCombie, John S.L. and Anthony P. Thirlwall. Economic Growth and the Balance of Payments Constraint. New York: St Martin's Press, 1994.

Myrdal, Gunnar. Monetary Equilibrium. New York: Augustus M. Kelley, [1939]1965. 
"A Methodological Note on the Principle of Cumulation." In An American Dilemma: The Negro Problem and Modern Democracy, Volume 2, by Gunnar Myrdal, pp. 1065-1970. New York and London: Harper \& Row, 1944. Reprinted in Gunnar Myrdal, Value in Social Theory: A Selection of Essays on Methodology, by Gunnar Myrdal, edited by Paul Streeton, pp. 198-205. London: Routledge and Kegan Paul, 1958.

—. "The Principle of Circular and Cumulative Causation." In Economic Theory and Under-developed Regions, by Gunnar Myrdal, pp. 11-22. London: Methuen and Co., Ltd., 1957.

—. "Appendix 2: The Mechanism of Underdevelopment and Development and a Sketch of an Elementary Theory of Planning for Development. 1. Circular Causation.” In Asian Drama: An Inquiry into the Poverty of Nations, Volume 3, by Gunnar Myrdal, pp. 1843-1859. Harmondsworth: Penguin Books, 1968.

O'Hara, Phillip Anthony. Marx, Veblen and Contemporary Political Economy: Principles and Unstable Dynamics of Capitalism. Cheltenham, UK \& Northampton, U.S.: Edward Elgar Publishing, 2000.

—. "Wealth Distribution and Global Inequality in the Multiple Capital Paradigm." International Journal of Human Development 1, 1 (2001): 121-140.

—. "Principles of Institutional-Evolutionary Political Economy-Converging Themes from the Schools of Heterodoxy." Journal of Economic Issues 41, 1 (2007a): 1-42.

—. "Heterodox Political Economy Specialization and Interconnection-Concepts of Contradiction, Heterogeneous Agents, Uneven Development." Intervention Journal of Economics 4, 1 (2007b): 99. 120 .

"Desarrolo desigual, desigualdad global y sostenibilidad ecologica: tendencias y patrones recientes", CLM Economia 10 (2007c): 163-192.

Pini, Paolo. "Economic Growth, Technological Change and Employment" Empirical Evidence for a Cumulative Growth Model with External Causation for Nine OECD Countries: 1960-1990.” Structural Change and Economic Dynamics 6 (1995): 185-213.

Setterfield, Mark. “'History Versus Equilibrium' and the Theory of Economic Growth.” Cambridge Journal of Economics 21 (1997): 365-378.

—. "Cumulative Causation, Interrelatedness and the Theory of Economic Growth: A Reply to Argyrous and Toner." Cambridge Journal of Economics 25 (2001): 107-112.

Sherman, Howard and David X. Kolk. Business Cycles and Forecasting. New York: Harper Collins, 1996.

Skott, Peter. "Kaldor's Growth Laws and the Principle of Cumulative Causation." In Growth, Employment and Inflation: Essays in Honour of John Cornwall, edited by Mark Setterfield, pp. 166-179. New York: St Martin's Press, 1999.

Tarkowski, Jacek. "The Polish Crisis and Myrdal's Model of Cumulative Causation." Political Studies 36, 3 (1988): 463-74.

Toner, Phillip. Main Currents of Cumulative Causation. London: Macmillan, 1999.

—. "'History versus Equilibrium' and the Theory of Economic Growth, by Mark Setterfield: A Comment." Cambridge Journal of Economics 25 (2001): 97-102. 
Copyright of Journal of Economic Issues is the property of Association for Evolutionary Economics and its content may not be copied or emailed to multiple sites or posted to a listserv without the copyright holder's express written permission. However, users may print, download, or email articles for individual use. 